\title{
鋼繊維一七メント系マトリックス間の付着破壊進展 機構と鋼繊耀補強モルタルの高靶性化
}

\author{
五十嵐心一*・川村満紀 ${ }^{* *}$
}

\begin{abstract}
シリカフュームの混入, 水セメント比の低減および細骨材の混入が鋼纎維一セメント マトリックス界面領域の破壊勒性之摩擦抵抗に及ぼす影響を付着破壊進展過程の特徽之 関連付けながら論じた，その結果, 緻密な界面領域の形成が必ずしも界面領域の破壊靯 性の増大をむたらすとは限らないこと, および付着破壊は単純な害界面の破壊ではな く, 繊維に沿う比較的広範囲の領域が破壊され，これが界面領域の破壊靱性と摩擦抵抗 に影響をおよぼすことを明らかにした。
\end{abstract}

Key Words : interfacial zone, fracture toughness, frictional stress, fluorescence microscope

\section{1. まえがき}

一般に繊維補強セメント系複合材料の靱性はその材料 が破壊にいたるまでに吸収したエネルギーにより評価さ れ，その吸収エネルギーの大部分はマトリックスにひび われが発生した後の繊維の引き抜け過程の吸収エネル ギーによりもたらされる ${ }^{1), 2)}$. したがって, 繊維補強セメ ント系複合材料が大きな䩶性を発揮するためには，マト リックスのひびわれを架橋する繊維が大きな引き抜き抵 抗を発揮しつつ破断することなく引き抜けることが肝要 である. 繊維の引き抜き抵抗は繊維の付着試験により評 価されるが, 緎維の特殊な形状に起因するアンカー効果 がないならば，その引き抜き抵抗は繊維一マトリックス 界面領域の特性を反映したものとなる.この場合, 繊維 の引き抜けに対する抵抗は, 繊維とマトリックスが完全 に付着を保持する段階におけるせん断抵抗と既に付着破 壊を生じた界面に作用する摩擦力によって発揮されると 考えられるが, 両者を区別して評価した研究は非常に少 ない. 一方, 近年, コンクリートへの破壊力学の適用が 積極的に検討されており, 繊維や骨材などのインクルー ジョンとセメント系マトリックス間の付着特性の評価に 破壊力学パラメー夕を用いることが提案されている3 ${ }^{3)}$. これらの研究においては, 付着破壊を繊維一マトリック ス界面のひびわれの進展とみなし, 界面における破壊䩲 性值により繊維の付着強度が評価される.さらに, その 手法においては, 既に付着破壊を生じた界面に作用する 摩擦抵抗を分離して評価することが可能である.また, 最近, 著者らは鋼繊維一セメント系マトリックス界面領 域の破壊勒性を実験的に求める方法を提案した4).

セメント系材料のように多孔性の材料の強度を増大さ

\footnotetext{
*正会員 博（工） 金沢大学助手 工学部土木建設工学科

（宁920 金沢市小立野 2-40-20）
}

**正会員 工博 金沢大学教授 工学部土木建設工学科
せるためには，欠陥となる細孔の量や最大細孔径を減少 させて緻密な組織を形成させればよい. bulk セメント ペースト相（鋼繊維の影響を受けない領域）とは異なる 組織を有する鋼繊維一七メントマトリックス界面領域の 組織においてもその組織の緻密化ににより繊維の付着強 度は増大すると考えられている ${ }^{5)}$. 界面領域の組織を緻 密化する方法としては, 水セメント比の低減およびシリ

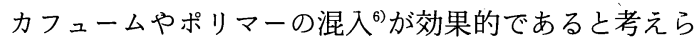
れ, Bentur '\& Cohen") $^{7)}$ はリカフュームを混入すると 界面領域の組織が緻密になることを走査型電子顕微鏡観 察により明らかにしている. また，ひびわれの捕捉作用 (アレスト作用) による靶性の増大という見地からは, 界 面領域に骨材粒子を分散させてひびわれの進展に対する 抵抗性を増大させることも考えられる.しかし，そのよ うな界面領域の緻密化や高靶性化を界面ひびわれの進展 の特徴および繊維のマトリックスからの引き抜け挙動と 関連づけながら検討した例はないようである.

本研究は, シリカフュームの混入, 水セメント比の低 減および細骨材の混入が鋼繊維一マトリックス界面領域 の破壊勒性と摩擦抵抗に及ぼす影響を明らかにし, その 結果を付着破壊進展過程の特徵と関連づけながら論ずる ことを目的とする.さらに, 界面領域の靱性の増大を目 的としてマトリックスに短炭素繊維を混入した場合にお ける繊維一マトリックス間の付着特性の変化が鋼繊維補 強モルタルの変形挙動におよぼす影響についても検討す る.

\section{2. 実験方法}

\section{（1） 使用材料および配合}

使用したセメントは普通ポルトランドセメントであ る. 細骨材には，標準砂および川砂を用いた，使用した 鋼繊維は直径が $0.5 \mathrm{~mm}$ または $0.6 \mathrm{~mm}$ のストレート繊 維である. 繊維の引き抜き試験においては, 埋め込み長 
Table 4 Mix Proportions of Cement Paste and Mortar Matrices Used for the Pull-out Test

\begin{tabular}{|c|c|c|c|c|}
\hline $\begin{array}{l}W / C \\
(\%)\end{array}$ & $\begin{array}{l}\text { Silica Fume } \\
\text { Replacement } \\
(\%)\end{array}$ & $\begin{array}{l}\text { Carbon Fiber } \\
\text { Content } \\
(\%)\end{array}$ & $\begin{array}{l}\text { Dosage of } \\
\text { Superplasticizer } \\
(\text { wt\% Cement) }\end{array}$ & Matrix \\
\hline $\begin{array}{l}55 \\
35 \\
25 \\
55 \\
55 \\
55 \\
55 \\
55 \\
55 \\
55 \\
55\end{array}$ & $\begin{array}{r}0 \\
0 \\
0 \\
10 \\
20 \\
0 \\
10 \\
0 \\
10 \\
0 \\
10\end{array}$ & $\begin{array}{l}0 \\
0 \\
0 \\
0 \\
0 \\
0 \\
0 \\
0 \\
0 \\
0.5 \\
0.5\end{array}$ & $\begin{array}{l}0 \\
0 \\
2.4 \\
0.6 \\
0.6 \\
0 \\
0.6 \\
0 \\
0.6 \\
0.8 \\
0.8\end{array}$ & $\begin{array}{l}\text { paste } \\
\text { paste } \\
\text { paste } \\
\text { paste } \\
\text { paste } \\
\text { mortar (Toyoura Sand) } \\
\text { mortar (Toyoura Sand) } \\
\text { mortar(River Sand) } \\
\text { mortar(River Sand) } \\
\text { mortar(River Sand) } \\
\text { mortar(River Sand) }\end{array}$ \\
\hline
\end{tabular}

Table 5 Mix Proportions of Steel Fiber Reinforced Mortars

\begin{tabular}{|c|c|c|c|c|c|c|}
\hline $\begin{array}{l}W / C \\
(\%)\end{array}$ & Cement & $\begin{array}{l}\text { Silica } \\
\text { Fume }\end{array}$ & Sand & $\begin{array}{l}\text { Dosage of Superplasticizer } \\
(\text { wt\% Cement) }\end{array}$ & Steel Fiber & $\begin{array}{l}\text { Vf }(\%) \\
\text { Carbon Fiber }\end{array}$ \\
\hline $\begin{array}{l}55 \\
55 \\
55 \\
55 \\
55 \\
55 \\
55 \\
55\end{array}$ & $\begin{array}{l}1 \\
0.9 \\
1 \\
0.9 \\
1.9 \\
0.9 \\
1.9 \\
0.9\end{array}$ & $\begin{array}{ll}\vdots & 0 \\
\vdots & 0.1 \\
\vdots & 0 \\
\vdots & 0.1 \\
\vdots & 0 \\
\vdots & 0.1 \\
\vdots & 0.1\end{array}$ & $\begin{array}{l}1.5 \\
1.5 \\
1.5 \\
1.5 \\
1.5 \\
1.5 \\
1.5 \\
1.5\end{array}$ & $\begin{array}{l}0 \\
0.6 \\
0.8 \\
0.8 \\
0 \\
0.6 \\
0.8 \\
0.8\end{array}$ & $\begin{array}{l}0 \\
0 \\
0 \\
0 \\
1.0 \\
1.0 \\
1.0 \\
1.0\end{array}$ & $\begin{array}{l}0 \\
0 \\
0.5 \\
0.5 \\
0 \\
0 \\
0.5 \\
0.5\end{array}$ \\
\hline
\end{tabular}

Table 1 Physical Properties of Silica Fume

\begin{tabular}{lccc}
$\begin{array}{l}\text { Specific } \\
\text { Gravity }\end{array}$ & $\begin{array}{c}\text { Bulk Density } \\
\left(\mathrm{g} / \mathrm{cm}^{3}\right)\end{array}$ & $\begin{array}{l}\text { Specific Surface } \\
\text { Area }\left(\mathrm{m}^{2} / \mathrm{g}\right)\end{array}$ & $\begin{array}{l}\text { Particle } \\
\text { Size }\end{array}$ \\
\hline 2.33 & 0.2 & 24.2 & $0.1-0.3$ \\
\hline
\end{tabular}

Table 2 Chemical Composition of Silica Fume (\%)

\begin{tabular}{llllllll}
\hline $\mathrm{SiO}_{2}$ & $\mathrm{Fe}_{2} \mathrm{O}_{3}$ & $\mathrm{Al}_{2} \mathrm{O}_{3}$ & $\mathrm{Ca} 0$ & $\mathrm{Mg} 0$ & $\mathrm{C}$ & $\mathrm{Na}_{2} 0$ & $\mathrm{~K}$ \\
\hline 87.44 & 6.94 & 0.30 & 0.20 & 0.41 & 1.11 & 0.19 & 1.00
\end{tabular}

Table 3 Physical Properties of Carbon Fiber

\begin{tabular}{ccccc}
\hline $\begin{array}{l}\text { Specific } \\
\text { Gravity }\end{array}$ & $\begin{array}{l}\text { Number of } \\
\text { Filaments } \\
\text { per Strand }\end{array}$ & $\begin{array}{c}\text { Diameter } \\
\text { Filament } \\
(\mu \mathrm{m})\end{array}$ & $\begin{array}{r}\text { Tensile } \\
\text { Strength } \\
\text { (GPa) }\end{array}$ & $\begin{array}{c}\text { Young's } \\
\text { Modulus } \\
(\mathrm{GPa})\end{array}$ \\
\hline 1.90 & 4000 & 17 & 1.8 & 180 \\
\hline
\end{tabular}

さが $30 \mathrm{~mm}$ になるように所定の長さに切断したものを 用いた。 また，鋼繊維補強モルタルに使用した鋼繊維の 長さは $20 \mathrm{~mm}$ である. 添加したシリカフュームの物理 的性質および化学成分を Table 1 および Table 2 に示 す。使用した炭素繊維は石炭ピッチ系の炭素繊維（長さ : $3 \mathrm{~mm}$ ) であり，その物理的性質を Table 3 に示す. 鋼 繊維の引き抜き試験用供試体のマトリックスおよび鋼繊 維補強モルタルの配合はそれぞれ Table 4 および Table 5 に示すとおりである.

\section{（2）鋼繊維の引き抜き試験}

鋼繊維の引き抜き試験に用いた供試体を Fig. 1 に示 す. 肉厚が $0.25 \mathrm{~mm}$ のシリコンチューブを鋼瀻維に装 着してセメントペーストまたはモルタルを打設した．打 設後 18 時間にてこのシリコンチューブを注意深く抜き 取ることにより鋼繊維一マトリックス界面に切欠きを導 入した後, 水中養生 $\left(20^{\circ} \mathrm{C}\right)$ を行った. 䋐維の埋め込み
長さは $30 \mathrm{~mm}$ であり, 切欠き長さは 5,10 および $15 \mathrm{~mm}$ と変化させた。材令 14 日および 28 日において Fig. 2 に 示す方法による鋼繊維の引き抜き試験によって荷重一変 位曲線を得た. 荷重一変位曲線の立ち上がり部のコンプ ライアンスの変化から, 以下の式によって界面領域の破 壊勒性 $(\Gamma)$ を求めた ${ }^{4}$. なお, 繊維の引き抜きに扔いて は, 繊維のポアッソン効果掞よび載荷重の偏心を考慮す ると, 界面ひびわれの進展はモード I, II および亚の混 合モードであると考えられる. しかし, 式 (1) にて求 められる值はモードாが卓越した混合モード下の破壊エ ネルギーとしての意味を持つことになる.

$$
\begin{aligned}
& \Gamma=P_{b}{ }^{2} / 2 \pi D(d C(a) / d a) \\
& P_{b}=P_{\max }-\tau_{f} \pi D 1_{\text {f,net }} \ldots \ldots \ldots \ldots \ldots \ldots . . .
\end{aligned}
$$

ここに,

$P_{b}$ : 最大引き抜き荷重 $\left(P_{\text {max }}\right)$ から摩擦抵抗の寄与を差 し引いた荷重

$C:$ コンプライアンス

$a:$ 切欠き長さ

$D:$ 繊維の直径

$\tau_{f}:$ 付着破壊界面に作用する摩擦応力

$l_{f, n e t}:$ 繊維の正味埋め込み長さ

付着破壊界面に作用する摩擦応力 $\tau_{\mathrm{f}}$ は一定であると仮 定し，最大引き抜き荷重に到達した時点からさらに変位 が $0.1 \mathrm{~mm}$ だけ増加するときの荷重一変位曲線下の面積 から $\tau_{\mathrm{f}}$ を求めた

\section{（3）鋼繊維の引き抜け過程の蛍光顕微鏡観察}

a）单一繊維の引き抜き試験

ブリーディングによる鋼繊維まわりの水膜およびェン トラップトエアーの形成を最小限にするために，Fig. 3 （a）に示すように，鋼瀻維をその中心軸が鉛直となるよ 


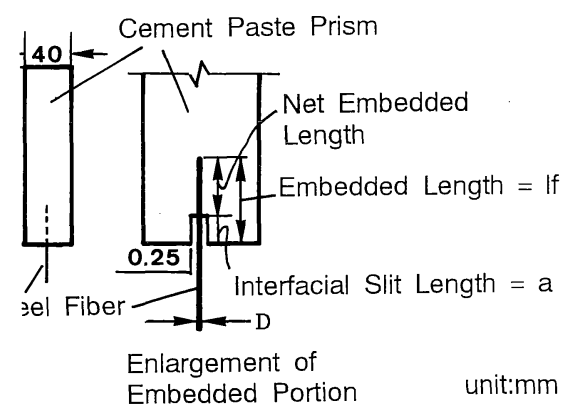

Fig. 1 Diagram of the specimen for the single fiber pull-out test

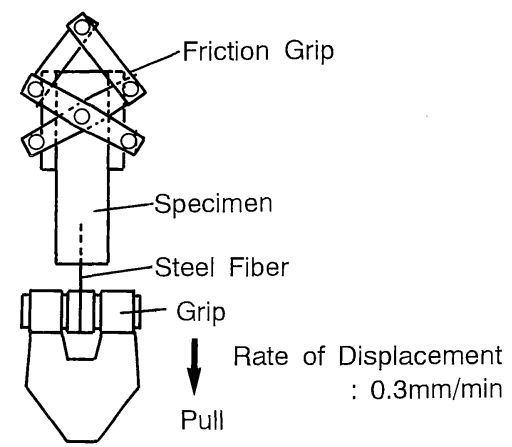

Fig. 2 Loading apparatus for the single fiber pull-out test

el Fiber

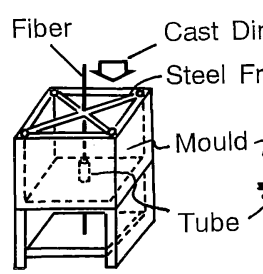

(a)

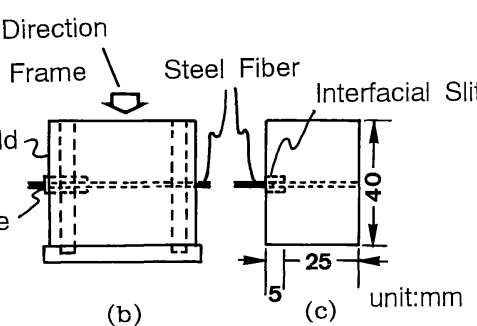

(b)

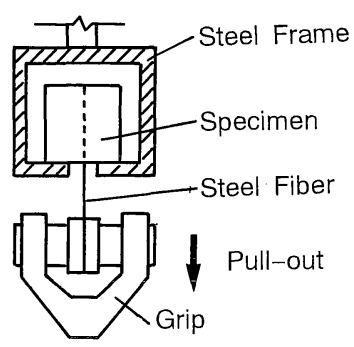

Fig. 5 Wedge opening loaded

Fig. 3 Mould for making specimens : (a) Fiber fixed in the vertical direction (b) Fiber fixed in the horizontal direction (c) Specimen size

Fig. 4 Loading apparatus to pull out a steel fiber for the fluorescence microscopic examinations specimen

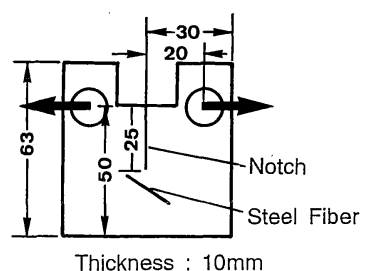

うに固定することができる型枠を真空デシケー夕に静置 し, 脱気を行った. 脱気終了後, 別途に真空摫拌装置を 用いて練り混ぜておいたセメントペーストを静かに型枠 に注ぎ込んで， $4 \times 4 \times 3 \mathrm{~cm}$ の供試体を作成した。 マト リックスとしてモルタルを用いる場合は，Fig. 3 (b) に 示すように鋼繊維を水平に配置して，大気中にてモル夕 ルを打設した．打設された供試体には前述のように，シ リコンチューブを用いて界面に長さ $5 \mathrm{~mm}$ の切欠きを導 入し，材令 28 日まで水中養生を行った，材令 28 日にお いて, Fig. 4 に示した載荷方法により鋼繊維を所定の荷 重レベルまで引き抜いた。 引き抜き終了後, 繊維の配列 方向と平行に鋼瀻維を含む面で切断して薄板（厚さ約 3 $\mathrm{mm}$ ）を切り出し，これを乾燥収縮ひびわれの発生を防 止するとともにエポキシを正常に硬化させるためにエ夕 ノールに 24 時間浸漬した. エタノール浸漬終了後, 薄板 を真空デシケータに入れて脱気し, 蛍光染料含有エポキ シ樹脂を薄板に含浸させた，樹脂の硬化後，表面の余分 なエポキシ樹脂をダイヤモンドカッターで取り除き，そ の表面を耐水研磨紙を用いて繊維の中心軸を含む面が現 れるまで注意深く研磨した. 研磨した試料表面を B 励起 （波長 450４90nm）の条件のもとで落射型蛍光顕微鏡 を用いて観察した.

b）〈さび押し込み式コン゙パクトテンション試験
Fig. 5 に示すように, 切欠きの前方に切欠きの方向に 対する傾き角が $45^{\circ}$ になるように鋼繊維を配置したコン パクトテンション試験片を作製した，供試体は水中養生 $\left(20^{\circ} \mathrm{C}\right)$ を行い，材令 28 日において，切欠き端開口変位 が $0.2 \mathrm{~mm}$ になるまでくさびを押し込み，切欠きから瀻 維に向かってひびわれを進展させた. 載荷終了後, a) と 同様にして蛍光染料含有エポキシ樹脂を供試体全体に含 浸させ，蛍光顕微鏡を用いてひびわれと繊維の交点付近 のマトリックスの破壊状況の観察を行った.

\section{（4）鋼繊維補強モルタルの曲け強度}

JIS R 5201 にしたがってモルタルを練り混ぜた後, 鋼縅維を 30 秒間にわたって投入し，さらに 30 秒間練り 混ぜた後鋼繊維補強モルタル供試体 $(4 \times 4 \times 16 \mathrm{~cm})$ を作 製した．長さ $3 \mathrm{~mm}$ の炭素瀻維をマトリックスに混入す る場合は，砂およびセメントと同時に炭素繊維を投入し てモルタルの練り混ぜを行った. 作製された供試体は 28 日間水中養生後, 中央集中載荷による曲げ試験を行い荷 重一たわみ曲線を記録した．また，マトリックス自身の 強度特性を知るために, 鋼瀻維を混入していない供試体 $(\phi 5 \times 10 \mathrm{~cm}, 4 \times 4 \times 16 \mathrm{~cm}, 4 \times 4 \times 30 \mathrm{~cm})$ を作製し, 割裂 引張強度試験, 圧縮強度試験, 曲げ強度試験, および RILEM の方法 ${ }^{8}$ に基づいた切欠きはりの 3 点曲げ試験 （スパン長さ： $24 \mathrm{~cm}$ ）を行い, マトリックスの強度と破 


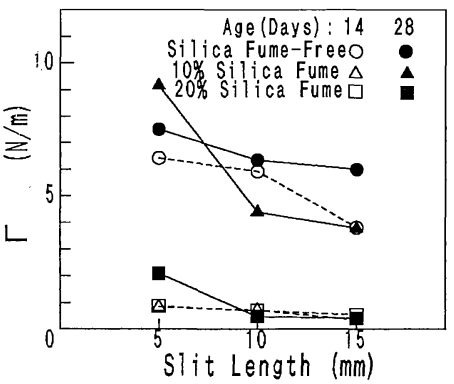

Fig. 6 Fracture toughness for the interfacial zone in the cement paste specimen with and without silica fume

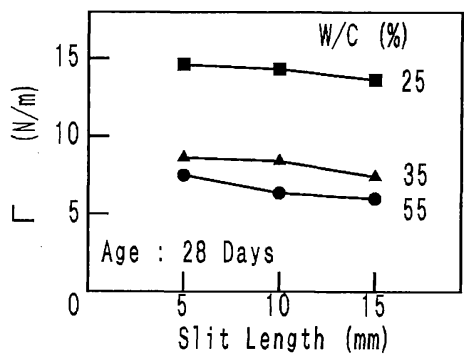

Fig. 7 Fracture toughness for the steel fiber-cement paste interfacial zone at various water : cement ratios

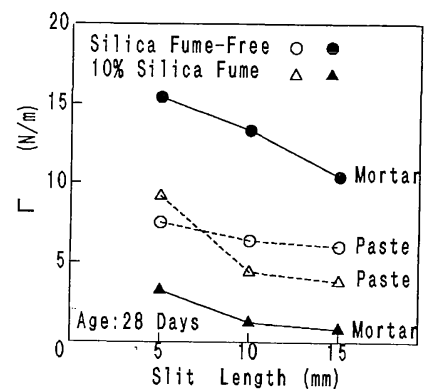

Fig. 8 Comparison of fracture toughness between the steel fibercement paste and mortar interfacial zone
壊エネルギーを求めた。

\section{3. 結果および考察}

\section{（1）鋼繊維一セメント系マトリックス界面領域の破 壊靯性}

a）シリカフュームの混入および水セメント比の破 壊鞇性に及ぼす影響

Fig. 6 にシリカフュームの混入の有無による鋼緎維一 セメントペースト界面領域の破壊勒性の相違を示す。切 欠き長さの増大とともに界面領域の破壊勒性は低下す る.このことは, 正味の繊維の埋め込み長さをリガメン 卜と見なすならば，モード I の破壊の場合と同様に界面 領域の破壊鞇性はリガメント長さに依存したパラメー夕 であることを示している. 材令 14 日においては, シリカ フューム混入セメントペースト中の界面領域の破壊靱性 は普通セメントペーストよりも著しく低い值を示ず。し かし, その後置換率 10\%の場合は破壊勒性の増大が認め られ，材令 28 日に打いては普通セメントペーストと同 程度の值を示すようになるのに対して, 置換率 $20 \%$ のむ のでは, 材令 28 日においても材令 14 日のあのと同程度 の低い破壊勒性を示す。

Fig. 7 は普通セメントペーストマトリックスの水セメ ント比の変化が界面領域の破壊勒性に及ぼす影響を示し たあのである. 水セメント比の低下にともない界面領域 の破壊勒性值は増大し, 特に水セメント比が $25 \%$ の場合 は水セメント比 $55 \%$ の場合の約 2 倍の值を示す.

一般に，繊維とマトリックス間の界面領域の組織は bulk セメントペースト相よりあ多孔質であり，これは セメントがまた固まらない状態におけるブリーディング の発生および繊維表面の水膜の形成, さらに平均粒子径 が数 $10 \mu \mathrm{m}$ のセメント粒子ではこの領域を効果的に充填 できないためであるとされている6). シリカフュームの 混入はブリーディングを滅少させ，またシリカフューム は粒子径がセメント粒子よりも 2 オーダー程度小さいこ とから，セメント粒子では充填できないような空隙を充
填することが可能である. 一方，水セメント比の低減に よってもブリーディングが軽減され界面領域は維密化さ れる. 実際, 著者らはいずれの場合も bulk セメント ペーストより硬度の低い界面領域は, シリカフュームの 添加および水セメント比の低減によってより緻密な組織 となることを微小硬度測定により明らかにしている ${ }^{4), 9}$. しかし，そのような緻密な界面領域の形成にあかかわら ず, Fig. 6 に示すようにシリカフュームの混入により界 面領域の破壊勒性は低下している。この結果より, 緻密 な界面領域の形成が必ずしも破壊勒性を増大させるとは 限らないことが分かる．また，いずれにおいても界面領 域は緻密化されるが，シリカフュームの混入と水セメン 卜比の低減により形成される緻密な界面領域の微視的構 造は相違し, その結果, 両者間で界面ひびわれの進展過 程も異なったものになると考えられる.

b）細骨材の混入が界面領域の破壊靯性に及ぼす影 響

Fig. 8 はマトリックスとしてモルタルを使用した場合 の界面領域の破壊䩲性をセメントペーストの場合と比較 して示したものである. 普通モルタルマトリックスの場 合はセメントペーストの場合よりあ大きな破壊勒性值を 示すのに対し，シリカフューム混入マトリックスにおい ては，モルタルマトリックスの方がセメントペーストマ トリックスよりあかなり低い破壊鞀性を示す．砂粒子は 界面ひびわれの進展を拘束するように作用すると考えら れるが，Fig. 8 の結果より，シリカフュームの混入によ り砂粒子のひびわれの進展に対して果たす役割が変化し ていることがわかる.

\section{（2）鋼繊維の引き抜け過程の蛍光顕微鏡観察}

Photo 1 (a) および（b）は普通セメントペーストか ら最大引き拔き荷重の $25 \%$ および $50 \%$ の荷重レベルま で鋼繊維を引き抜いたときの鋼瀻維一セメントペースト 界面領域の付着破壊の進行過程を示したものである. 蛍 光顕微鏡観察では，ひびわれや多孔質部分により多くの 蛍光染料含有樹脂が侵入することによる蛍光の強度の増 


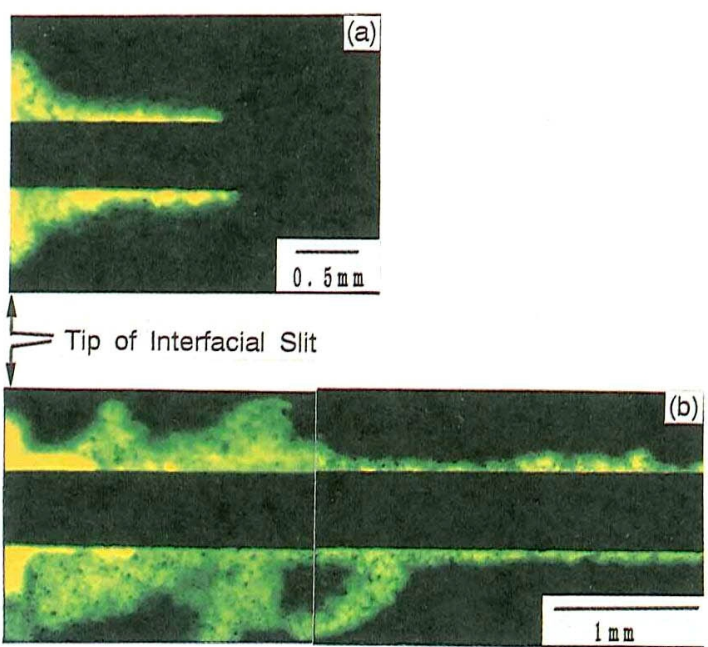

Photo 1 Progressive debonding in the interfacial zone between a vertical steel fiber and the silica fume -free cement paste (a) at a pull-out load of 14.7 $\mathrm{N}$ (b) at a pull-out load of $29.4 \mathrm{~N}$

大を利用する ${ }^{10)}$ ．すなわち，発生する蛍光の強度はその 部分のひびわれや微視的破壊の程度の増大とと屯に大き くなると判断される.

これらの荷重レベルにおける鋼䋐維の引き拔き段階で は，付着破壊部分と繊維とマトリックスが付着を保持す る部分の 2 つの領域が存在することが理論的に推定され ている11.12). Photo 1 より，その両者が存在することが 確認できるが，付着破壊は鋼繊維一マトリックス実界面 の剝離だけではなく，比較的広範囲の領域の破壊をと屯 なっていることがわかる．引き抜き荷重レベルが $25 \%$ （引き抜き荷重：14.7N）では, 界面切欠き先端部から約 $1.5 \mathrm{~mm}$ にわたって蛍光領域が観察され, その幅は約 $100 \mu \mathrm{m}$ である. $50 \%$ の荷重レベル（引き抜き荷重：29.4 N）では，付着破壊している部分の長さは約 $4 \mathrm{~mm}$ であ り, 蛍光領域の最大幅は約 $500 \mu \mathrm{m}$ に達する. Photo 2 は シリカフューム混入セメントペーストから $50 \%$ の荷重 レベルまで鋼繊維を引き抜いたときの界面領域を示した あのである. Photo 1 と同様に, 緎維周辺のマトリック スの破壊を示すコーン状の蛍光領域が観察され，その先 端は界面切欠き先端から約 $4 \mathrm{~mm}$ に達し，さらに前方の 界面領域には蛍光領域は観察されなかった，繊維の引き 抜き試験において，付着破壊が実際によ゙の部位からよ゙の ように進展していくのかについてはこれまでのところ明 らかではないとされてきたが(3)，Photo 1 および2より， 綫維の引き抜き試験においては, 比較的低い荷重レベル において部分的に付着破壊は発生し，これが䋐維の引き 抜きにとむない徐々に進展していくことがわかる。 た，綫維の引き抜きにとむなう破壊領域の幅は切欠き先 端部で大きく，切欠き先端から離れるにともない狭くな
る傾向が見られる。このことは切欠き先端部の応力集中 のために，より広い範囲のマトリックスが破壊されてい ることを示すものと考えられる.

Photo 1 および 2 にて示された部分的付着破壊を示す 蛍光領域の長さはこれまで理論的および実験的に推定さ れている付着破壊長さよりも短いょうである. Stang,

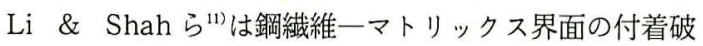
壊規準に界面の破壊仕事を用いて鋼瀻維の引き抜き過程 における引き抜き荷重と付着破壊長さの関係を導いてい る. Bijen \& Storoeven ${ }^{(4)}$ (鋼綫維のかわりに鋼板をコ ンクリートから引き抜き, そのときの界面の破壊の進行 をレーザーホログラフィーにより測定することによって 付着破壊長さに関する実験式を提案している. Fig. 9 は それらの提案式より得られる引き抜き荷重レベルと付着 破壊長さの関係を示す曲線之蛍光顕微鏡観察により得ら れたプロットを示したものである。引き抜き荷重が最大

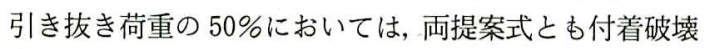
進行長さとして約 $9 \mathrm{~mm}$ の長さを与える. これに対して 蛍光顕微鏡観察によって得られる付着破壊長さは約 4 $\mathrm{mm}$ である.このような差異を生じた理由として, Stang ら"11のモデルにおける仮定が本実験にて観察され た付着破壊の進行過程とは異なることが挙げられる. Stang らのモデル(1)においては, 剛なマトリックス之薄 い界面層を仮定し, 解放されたひずみエネルギーは界面 ひびわれの進展に費やされるとしている。しかし，

Photo 1 および 2 に示したように，付着破壊は実界面部 分の剝離だけではなく比較的広範囲のマトリックスの破 壊をともない，これによってエネルギーが消費される. したがって, Fig.9において見られる理論式より推定さ れる付着破壊長さと本実験より得られる結果との相違は 理論式を導くための仮定が実際の破壊状況と異なるため と考えられる. また, Bijen \& Stroeven ${ }^{14)}$ の実験は鋼板 とコンクリートマトリックスより成る 2 次元的なモデル 供試体における鋼板に沿う付着破壊の進行をレーザーホ ログラフィーによって観察したものであり，本実験にお ける鋼䋊維のマトリックスからの付着破壊過程の観察之 はかなり大きく異なる.

Photo 3 (a) および（b）はそれぞれ普通セメントペー ストおよびシリカフューム混入ペーストから変位 $1 \mathrm{~mm}$ まで鋼繊維を引き抜いたときの界面の破壊の椂子を示し たあのである. いずれのセメントペーストマトリックス の場合む, 繊維の全埋め込み長さにわたって蛍光領域が 観察され，埋め込み長さ全体にわたって既に付着破壊が 生じている.また, 普通セメントペーストとシリカ フューム混入ペーストを比較すると, 䖢光領域の幅はシ リカフューム混入の場合の方が狭い.さらに，部分的に 付着破壊が進行している場合（Photo 1) と比較すると, 最大引き抜き荷重以後まで継続して引き抜きを行った場 


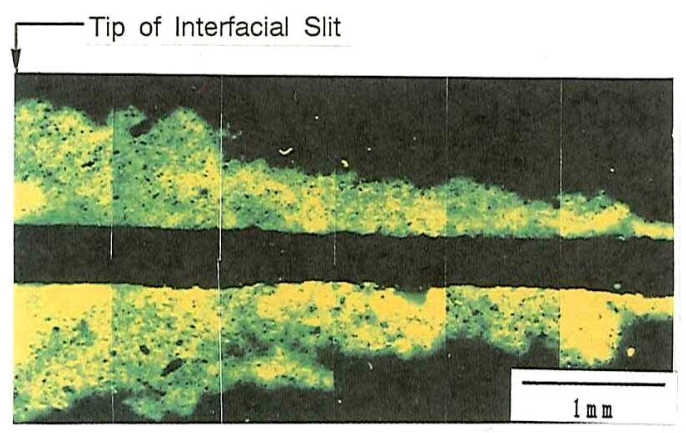

Photo 2 Interfacial zone in the 10\%silica fume-bearing cement paste at the pull-out load of half the maximum

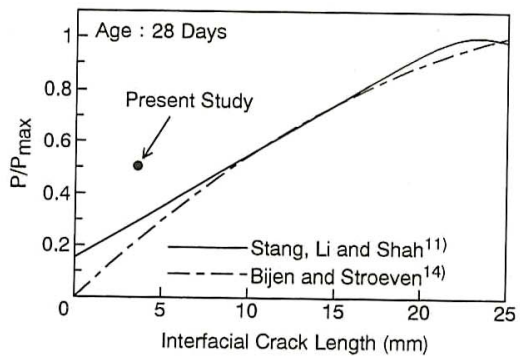

Fig. 9 Comparisons of the debonded length along the interface

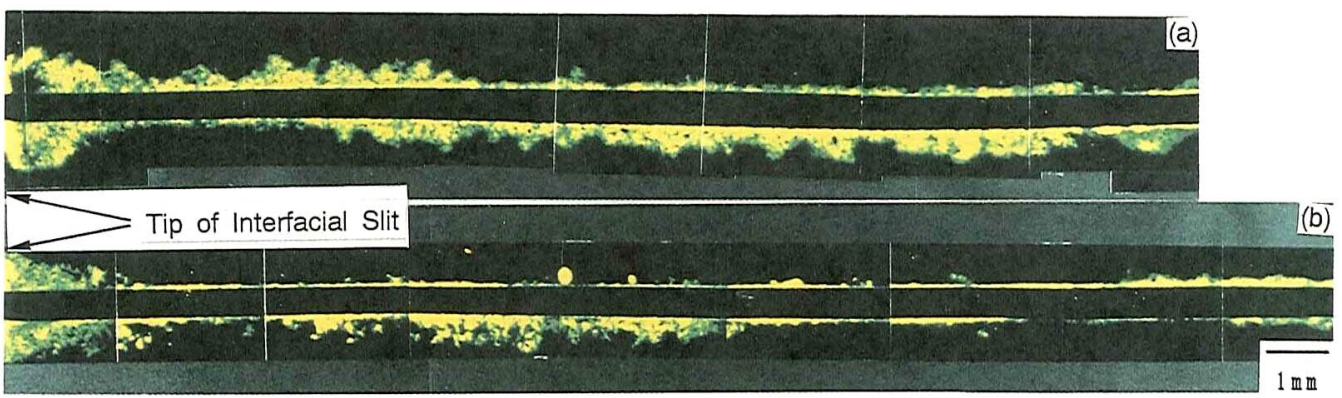

Photo 3 Interfacial zone between a steel fiber and the cement paste matrix after catastrophic debonding (a) silica fumefree (b) $10 \%$ silica fume-bearing

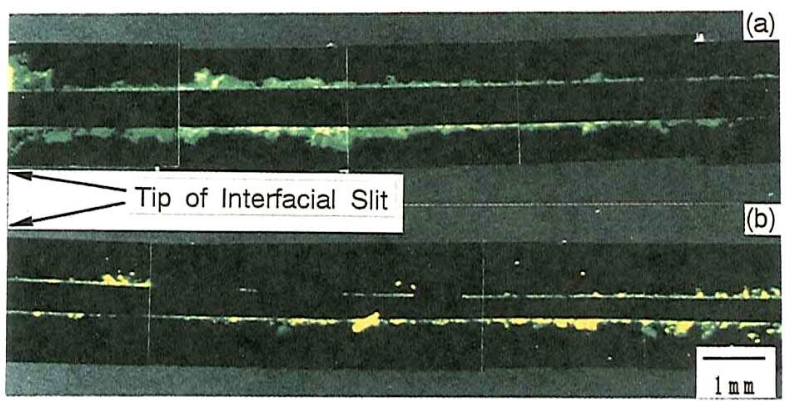

Photo 4 Interfacial zone between a steel fiber and the mortar matrix after catastrophic debonding (a) silica fumefree (b) $10 \%$ silica fume-bearing

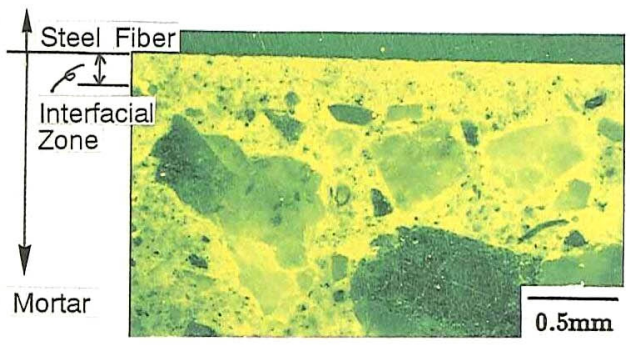

Photo 5 Distribution of fine aggregate particles in the interfacial zone
合 (Photo 3) の方が蛍光領域の幅が大きい.このことは いったん付着破壊を生じた界面はその後の繊維のすべり 過程でのマトリックスとの接触摩擦によりマトリックス がさらに崩壊していくことを示している. しかし，シリ カフューム混入セメントペーストにおいてはその破壊領 域の拡大の程度は普通セメントペーストよりあ小さく, 繊維の引き抜き過程において損伤を受ける領域はかなり 限られたものになるといえる.このように, シリカ フュームの混入により破壊領域の大きさが小さくなる傾 向はモルタルマトリックスの場合にも認められる (Photo 4). 特に, シリカフューム混入モルタルの破壊 領域はシリカフューム混入ペーストのそれより小さく
なっていることが注目される.

（3）界面領域の破壊勒性之付着破壊進行過程の特徵 との対応

硬化セメントペーストでは, 未水和セメント粒子や $\mathrm{Ca}(\mathrm{OH})_{2}$ 結晶がひびわれの進展を妨げるように作用す ること ${ }^{15)}$ ，および硬化セメントペースト自身の不均質な 微視的構造に起因した微細なひびわれの発生と分岐に よってある程度の勒性が発揮されると考えられる ${ }^{16}$. 同 一の水セメント比のままシリカフュームを混入した場合 は, 全細孔量には変化はないが細孔は細分化される。さ らに, セメントの水和反応が促進されて未水和セメント 粒子が減少するとともに, ポゾラン反応により $\mathrm{Ca}(\mathrm{OH})_{2}$ 
の結晶も減少する. また，ポゾラン反応により $\mathrm{Ca}(\mathrm{OH})_{2}$ が存在していた部分には, 比較的大きな径の細孔が残さ れる17). したがって, シリカフューム混入セメントペー スト一鋼繊維の界面領域においては, 組織の不均質性に 起因した微細なひびわれがあまり発生することむなく， ひびわれの進展を妨げるような粒子も少ない.したがっ て, この場合, 界面ひびわれはあまり多くのひびわれを 発生させることなく進展するために, 繊維に沿う破壊領 域（蛍光領域）の面積は減少し, 界面領域の破壊靶性は 低下したものと考えられる。一方，水セメント比を低減 した場合は，反応生成物自体の表面エネルギーが増大す る ${ }^{18)}$ ともに全細孔量や最大細孔径が減少する.ささらに, 末水和セメント粒子や $\mathrm{Ca}(\mathrm{OH})_{2}$ 結晶粒子の数む多くな る.このように, 水セメント比の低減によってセメント ペーストの表面エネルギーが増大し, 欠陷寸法は減少す る.また, ひびわれの進展を妨げる粒子は増加するため に, 界面領域の破壊靱性が増大したと考えられる.

骨材粒子はひびわれの進展を妨げるので, 一般にセメ ントペーストよりもモルタルの方が破壊䩲性は大きくな る.しかし, Photo 5 に示すように, 繊維一モルタルマ トリックス界面領域に存在する砂粒子の数は少ない.こ のことが, シリカフュームを添加したモルタル一鋼繊維 界面領域においても, シリカフュームセメントペースト の場合（Fig. 6） と同様にその破壊靯性が増大しなかっ たことと関係していると考えられる. しかし, シリカ フューム添加モルタルにおける破壊靱性がシリカフュー ム添加セメントペーストにおけるそれよりあ小さくなる 原因は不明である.

Table 6 に異なるマトリックスにおいて付着破壊界面 に作用する摩擦応力を示す. シリカフュームの混入によ り摩擦応力は増大する傾向を示している. Photo 3 およ び 4 より明らかなように, 鋼繊維近傍の破壊領域（蛍光 領域）がシリカフュームの混入により小さくなるという ことは, シリカフュームの添加によって繊維の周囲に形 成される界面領域のせん断抵抗が増大したことを示すす のである. また, 実験によって得られる摩擦応力 $\left(\tau_{\mathrm{f}}\right)$ は 繊維周辺のある領域の破壊を生ずるのに要する抵抗力あ 含めた見かけの応力と考えられる. したがって, シリカ フューム含有マトリックス一鋼繊維における付着破壊界 面は普通セメントの場合よりあより大きな摩擦応力を発 揮できることになると考えられる.

\section{（4）鋼繊維補強モルタルの高靱性化機構に関する考} 察

Brandt ${ }^{19)}$ によると, 繊維補強セメントにおいて 1 本 の鋼繊維が引き抜けるときの全吸収エネルギーは以下の 5 成分からなるとしている。

1）マトリックスから繊維が付着破壊するときの吸収 エネルギー
Table 6 Frictional Shear Stress $\left(\tau_{\mathrm{f}}\right)$ of the Debonded Interface

\begin{tabular}{|c|c|c|c|c|}
\hline $\begin{array}{l}\text { Type of } \\
\text { matrix }\end{array}$ & $\begin{array}{l}W / C \\
(\%)\end{array}$ & Sili $\underset{(\%)}{\operatorname{ca}}$ Fume & $\underset{(\%)}{\text { Carbon Fiber }}$ & $\begin{array}{l}\tau \\
\left(M P^{\prime} a\right)\end{array}$ \\
\hline $\begin{array}{l}\text { paste } \\
\text { paste } \\
\text { paste } \\
\text { paste } \\
\text { paste }\end{array}$ & $\begin{array}{l}55 \\
35 \\
25 \\
55 \\
55\end{array}$ & $\begin{array}{r}0 \\
0 \\
0 \\
10 \\
20 \\
\end{array}$ & $\begin{array}{l}0 \\
0 \\
0 \\
0 \\
0\end{array}$ & $\begin{array}{l}0.74 \\
0.70 \\
2.37 \\
0.82 \\
2.57\end{array}$ \\
\hline $\begin{array}{l}\text { mortar } \\
\text { mortar }\end{array}$ & $\begin{array}{l}55 \\
55\end{array}$ & $\begin{array}{r}0 \\
10\end{array}$ & $\begin{array}{l}0 \\
0\end{array}$ & $\begin{array}{l}\text { 1. } 22 \\
\text { 2. } 44\end{array}$ \\
\hline $\begin{array}{l}\text { mortar } \\
\text { mortar } \\
\text { mortar } \\
\text { mortar }\end{array}$ & $\begin{array}{l}55 \\
55 \\
55 \\
55\end{array}$ & $\begin{array}{r}0 \\
10 \\
0 \\
10\end{array}$ & $\begin{array}{l}0 \\
0 \\
0.5 \\
0.5\end{array}$ & $\begin{array}{l}0.69 \\
0.87 \\
1.26 \\
1.28\end{array}$ \\
\hline
\end{tabular}

(values at the interfacial slit length of $15 \mathrm{~mm}$ )

2）付着破壊後摩擦力に抵抗しながら繊維が引き抜け る過程における消失エネルギー

3）ひびわれ面に対して傾いた繊維の曲げによる繊維 自身の塑性変形エネルギー

4）ひびわれ面に対して傾いた繊維が局所的に周囲の マトリックスを圧縮するときのマトリックスの圧 壊エネルギー

5）傾いた繊維がマトリックスを圧縮することによる 補足的な摩擦力の増加に対応するエネルギー増分 これらの 5 成分の内，1）は本実験における界面領 域の破壊靯性に対応し，2）は付着破壊界面の摩擦 応力 $\left(\tau_{\mathrm{f}}\right)$ と関係する.

Photo 6 はくさび押し込み試験におけるひびわれと繊 維の交点付近の破壊状況を示す蛍光顕微鏡写真である. この写真より, 繊維を境にしてひびわれが進行方向と垂 直方向にずれること，および繊維に沿って付着破壊が生 じていることがわかる，また，ひびわれの開口にともな い曲げを受ける繊維がマトリックスを押し付ける部分に 局所的な圧壊を示す三角形状の蛍光領域が認められる. この三角形状の蛍光領域は Brandt のモデルにおけるマ トリックスの圧壊に関係したエネルギー成分 3)，4）お よび 5）が実際の複合材料中においても存在することを 示唆する.このことより, 鋼繊維補強モルタルにおいて は，モルタルマトリックスの圧縮強度もその䩲性に影響 をおよぼすと推察される.

\section{（5）短炭素繊維混入によるモルタルの高靫性化}

単一繊維の引き抜き過程で繊維の近傍において破壊さ れるマトリックスの領域は比較的広範囲である。した がって, 繊維近傍の領域の強度および靶性を増大させる ことによって, 鋼繊維の付着強度および引き抜き吸収エ ネルギーは増大させることができると考えられる．ここ では，第 2 の繊維として短い炭素繊維をマトリックス中 に均一に分散させることによって鋼繊維とモルタルマト リックスの付着特性が改善される可能性について検討す る.

Fig. 10 はモルタルマトリックスに短炭素繊維および 


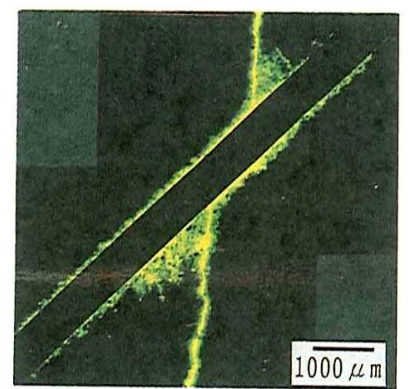

Photo 6 Interaction of an inclined fiber with a crack : Yielding of parts of the matrix due to the local compression

シリカフュームを混入した場合における鋼繊維一モルタ ルマトリックス界面領域の破壊勒性を示したものであ る. 普通モルタルに炭素繊維を混入すると界面領域の破 壊勒性值は大きく増大する傾向が認められる. 特に, 界 面切欠き長さが $15 \mathrm{~mm}$ の場合は普通モルタルマトリッ クスの約 2 倍の值を示す. また, シリカフューム混入モ ルタルにおいても短炭素織維を混入した場合, シリカ フュームの混入によって破壊靱性值は低下しない.

Table 6 にそれらのモルタルマトリックスから鋼䋐維を 引き抜いたときの付着破壊界面に作用する摩擦応力を示 した. 短炭素䋐維の混入により摩擦応力は著しく増大 し, シリカフュームと短炭素纎維を同時に混入した場合 あほぼ同程度の摩擦応力を示す。このことより, 短炭素 繊維をマトリックスに混入することは界面領域の破壊䩗 性を増大させるだけではなく, 付着破壊後の摩擦応力む 増大させ, 結局, 鋼瀻維の引き抜き過程における吸収エ ネルギーを増大させることがわかる.

Table 7 に各モルタルマトリックスの強度および破壊 エネルギーを示す．短炭素繊維を混入しただけでは，そ の繊維混入率が低いことおよび繊維長さが $3 \mathrm{~mm}$ 之骨材 寸法よりむ小さいこと, さらにその炭素繊維がモルタル の練り混ぜ中に破断してさらに短くなることなどにより 短炭素䋐維の補強効果は小さいようであるが，マトリッ クス自身の破壊エネルギーは増大する. 一方, シリカ フューム混入の効果は主に压縮強度の増大となって現 れ, 靶性を増大させる効果はない. しかし, シリカ フュームと短炭素緎維の両者を混入すると高い圧縮強度 が得られるとともに引張強度や勒性が増大することがわ かる.

Fig. 11 は異なるモルタルマトリックスを有する鋼瀻 維補強モルタルの荷重一たわみ曲線を示したあのであ る. 普通モルタルマトリックスの場合 (Fig.11 (a)), 荷 重はマトリックスの初ひびわれの発生にともない大きく 低下するが, その後たわみ $0.3 \mathrm{~mm}$ 付近から再び増大し ていく.しかし, ひびわれ後の最大耐荷力は初ひびわれ

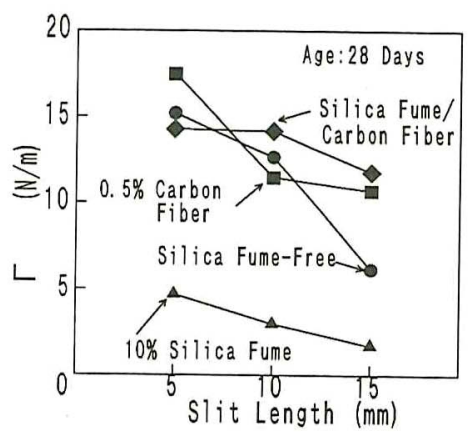

Fig. 10 Fracture toughness for the interfacial zone between a steel fiber and mortar matrix reinforced by carbon fibers

荷重よりは小さい. シリカフューム混入モルタルマト リックスの場合は (Fig.11 (b)), 初ひびわれ後にわずか に荷重の低下を示した後に急激に荷重は増大し, たわみ $0.5 \mathrm{~mm}$ 付近において初ひびわれ荷重よりむ大きな耐荷 力にいたる. 炭素繊維混入モルタルマトリックス (Fig. 11 (c)) では, 初ひびわ後の荷重低下を生じることな く变形が進行し，ほぼ弾塑性的な挙動を示す.シリカ フュームと炭素繊維を併用したモルタルマトリックスの 鋼䋐維補強モルタル（Fig.11（d））は，いずれの場合よ りあ大きな初ひびわれ荷重に達した後, 荷重は急激に増 大してかなり大きな耐荷力に達し, その後もその耐荷力 を保持したまま変形が進行していく. 異なるモルタルマ トリックス間における荷重一たわみ曲線形状の相達は主 に初ひびわれ後の变形挙動に現れていることから, その ような差異は鋼繊維の引き抜け特性之密接に関係してい ると考えられる.

シリカフューム混入モルタルマトリックス一鋼溨維界 面領域の破壊靯性は普通モルタルマトリックスの場合よ りむ小さいことから, シリカフューム鋼繊維補強モル夕 ルでは鋼緎維が付着破壊するまでに保持できる荷重は小 さいことになる，しかし，付着破壊界面に作用する摩擦 応力は普通モルタルよりも大きくなるために繊維は荷重 の負担に堪えることができ，また，モルタルマトリック スの圧縮強度が大きいためにマトリックスはひびわれ幅 の小さいうちは鋼繊維近傍におけるマトリックスの圧壊 は起こらずに鋼緎維の曲げ变形に抵抗しうる. したがっ て, シリカフューム混入鋼䋐維補強モルタルでは初ひび われにともなう荷重低下が抑制されたと考えられる. 短 炭素繊維混入マトリックスの場合は, 界面領域の破壊靭 性値および摩擦応力が普通モルタルの場合に比較して大 きいために，繊維一マトリックス間の付着破壊は生ずる ことなくさらに大きな荷重を負担し, マトリックスのひ びわれは安定に進展することが可能となる. また, マト リックスの初ひびわれ直後の開口幅の小さなひびわれを 
Table 7 Mechanical Properties of Several Matrices

\begin{tabular}{|c|c|c|c|c|}
\hline $\begin{array}{l}\text { Type of } \\
\text { Matrix }\end{array}$ & \multicolumn{3}{|c|}{ Strength $(\mathrm{MPa})$} & $\begin{array}{l}\text { Fracture } \\
\text { Energy }(\mathrm{N} / \mathrm{m}\end{array}$ \\
\hline $\begin{array}{l}\text { Control } \\
10 \% \text { Silica }\end{array}$ & $\begin{array}{l}2.87 \\
3.53\end{array}$ & $\begin{array}{l}7.72 \\
7.03\end{array}$ & $\begin{array}{l}36.2 \\
49.7\end{array}$ & $\begin{array}{l}77.47 \\
71.59\end{array}$ \\
\hline $0.5 \%$ Carbon & 2.68 & 6.23 & 36.6 & 169.7 \\
\hline $\begin{array}{l}\text { arbon fiber/ } \\
\text { silica Fume }\end{array}$ & 4.84 & 7. 47 & 47.8 & 189.3 \\
\hline
\end{tabular}

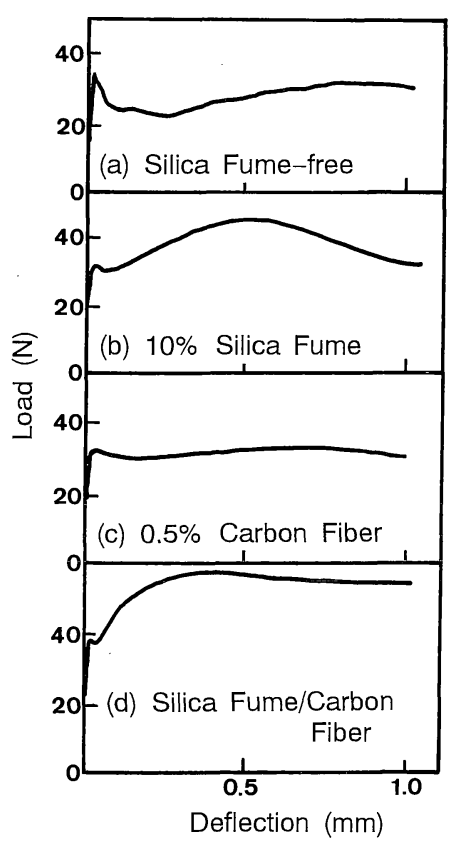

Fig. 11 Load-deflection curves of steel fiber reinforced mortars

炭素繊維が架橋することによって荷重低下が緩やかにな る効果も生じうる。このため, マトリックスの初ひびわ れにともなう急激な荷重低下が抑制されたと考えられ る. シリカフュームと短炭素繊維をマトリックスに混入 した鋼繊維補強モルタルの場合は，界面領域の破壊靭性 々摩擦応力の両方の増大により䋐維は大きな引き抜き抵 抗を発揮し，繊維を引き抜くために必要な荷重が増大す る.また，マトリックスの圧縮強度む大きいために Brandt のモデルにおけるエネルギー成分 3），4）および 5）の寄与屯大きいと考えられる.さらには，シリカ フュームは炭素繊維の分散性および付着強度を改善する ために炭素繊維緘維による微細なひびわれに対する架橋 効果も顕著となりマトリックスの靸性む増大するようで ある (Table 6). その結果, 複合材料の強度および夕フ ネスがともに増大したものと考えられる。このように， 繊維補強モルタルの曲げ特性はマトリックスにひびわれ が発生した後もマトリックス自体の強度特性の影響む受 ける. したがって, 高強度高勒性の鋼繊維補強セメント 系複合材料を得るためには，繊維一マトリックス界面領
域全体の破壊靱性抢よび付着破壊界面の摩擦抵抗を増大 させるとともに, マトリックス自体の圧縮強度の増大も 必要であるといえる.

\section{4. まとめ}

鋼繊維補強セメントの付着特性を界面領域の破壊勒性 と摩擦抵抗により評価し，その付着特性を鋼繊維補強モ ルタルの繊維架橋による高靶性化機構と関連づけながら 検討を行った．その結果，シリカフュームの混入による 緻密な界面領域の形成が必ずしあ纎維一マトリックス界 面領域の破壊靵性の増大をむたらすとは限らないこと, および鋼繊維の引き抜き過程において比較的広範囲の領 域が破壊され，付着破壊は単なる繊維一実界面間のせん 断破壊による剝離の進行ではないことが明らかになっ た. シリカフュームと短炭素䋐維をマトリックスに均一 に分散させることによりマトリックスの強度抢よび勒性 を増大させると界面領域の破壊靭性や摩擦抵抗 増大 し，そのことが鋼瀻維補強モルタルの強度および靶性の 増大につながることを示した，本研究により得られたそ の他の主な結果は以下のとおりである。

（1）鋼繊維一セメントペーストマトリックス界面領 域の破壊勒性は界面領域の細孔径分布と未水和セメント 粒子および $\mathrm{Ca}(\mathrm{OH})_{2}$ 結晶の存在と関係すると考えられ る.

（2）マトリックスの水セメント比の低減により鋼繊 維一マトリックス界面領域の破壊勒性は増大する。

（3）付着破壊の進展は界面領域だけではなく, bulk セメントペースト相までを含めた広範囲の領域の強度や 鞋性に影響される。

（4）鋼繊維の付着破壊は比較的低い引き抜き荷重に て部分的に発生しそれが徐々に進展していく。

（5）シリカフュームの混入により, 鋼繊維の引き抜 き過程において破壊される領域の幅は小さくなり，この ことは界面領域の破壊勒性の低下および付着破壊界面の 摩擦抵抗の增大と関係するようである.

謝辞 本研究をまとめるにあたり，指導，助言を賜りま した京都大学藤井學教授，同宮川豊章助教授に謝意を表 します．また，本研究の一部に対して土木学会吉田研究 奨励金および文部省科学研究費補助金 (試験研究 B)（研 究代表者：川村満紀）の交付を受けた。ここに記して謝 意を表します。

\section{参 考 文 献}

1）魚本健人・小林一輔・西村次男 : 鋼繊維補強コンクリ一 卜の曲げタフネス評価法, 生産研究, Vol. 34 , No. 12 , pp. 522-525, 1982.

2）三瀬貞・真嶋光保・宮武英次：各種繊維補強コンクリー トの比較試験, コンクリート工学年次講演会論文集, pp. 
$321-324,1984$

3) Morrison, J. K., Shah, S. F. and Jenq, Y-S : Analysis of fiber debonding and pullout in composites, Journal of Engineering Mechanics, ASCE, Vol. 114, No. 2, pp. 277-294, 1988.

4) Kawamura, M. and Igarashi, S. : Fracture toughness for the steel fiber-cement paste interfacial zone, Journal of Materials in Civil Engineering, ASCE, Vol. 4, No. 3, pp. 227-239, 1992.

5) Bentur, A., Gray, R. J. and Mindess, S. : Cracking and pull-out processes in fiber reinforced cementitious materials, Developments in Fiber Reinforced Cement and Concrete, RILEM Symposium, Vol. 2, pp. 393-399, 1986.

6) Mandel, J. A. and Said, S. 4: Effect of the addition of an acrylic polymer on the mechanical properties of mortar, ACI Materials Journal, Vol. 87, No. 1, pp. 54-61, 1990.

7) Bentur, A. and Cohen, M. D. : Effect of condensed silica fume on the microstructure of the interfacial zone in Portland cement mortars, Journal of American Ceramic Society, 70 [10] , pp. 738-743, 1987.

8) RILEM Draft Recommendation : Determination of the fracture energy of mortar and concrete by means of three-point bend tests on notched beams, Materials and Structures, Vol. 18, pp. 285-290, 1985.

9) Igarashi, S. and Kawamura, K. : Effects of the addition of silica fume and fine aggregate on the fracture toughness for the steel fiber-matrix interfacial zone, Fracture Processes in Concrete, Rock and Ceramics, Proc. of the Intl. RILEM/ESIS Conference, Vol. 1, pp. 307-316, 1991.

10) Jensen, A. D. et al : Petrographic analysis of concrete, Danish Building Export Council

11) Stang,H., Li,Z. and Shah, S.P. : Pull-out problem Stress versus fracture mechanical approach, ASCE
Journal of Engineering Mechanics, Vol. 116, No. 10, pp. 2136-2150, 1990.

12) Gray, R. J. : Analysis of the effect of embedded fiber length on fiber debonding and pull-out from an elastic matrix, Part 1: Review of theories, Journal of Materials Science, Vol. 19, pp. 861-870, 1984

13) General Discussion, Toughening Mechanisms in Quasi-Brittle Materials (ed. Shah, S. P.), Kluwer Academic Publishers, pp. 534-537, 1990.

14) Bijen, J. and Stroeven, P. : Holographic inter-ferometry study of debonding between steel and concrete, Research in Civil Engineering Materials, Annual Report 1988, Delft University of Technology, pp. 19-24, 1988.

15) Berger, R. I. : Calcium hydroxide : Its role in the fracture of tricalcium silicate paste, Science, Vol. 175 , pp. 626-629, 1971

16) Struble, L. J., Stutzman, P. E. and Fuller, E. R. : Microstructural aspects of the fracture of hardened cement paste, Journal of the American Ceramic Society, Vol. 72, No. 12, pp. 2295-2299, 1989.

17) Cheng-Yi, H. and Feldman, R. F. : Influence of silica fume on the microstructural development in cement mortars, Cement and Concrete Research, Vol. 15, pp. 285-294, 1985.

18) Mindess, S. : Relationships between strength and microstructure for cement-based materials : An overview, Very High Strength Cement-Based Materials (ed. Young, J. F.), Proc. MRS Symp., Vol. 42 , pp. $53-68,1985$.

19) Brandt, A. M. : On the optimization of the fiber orientation in cement based composite materials, Fiber Reinforced Concrete (ed. Hoff, G. C.), ACI SP -81, ACI, pp. 267-285, 1984.

(1993.12.21 受付)

\title{
FRACTURE PROCESS OF THE INTERFACIAL ZONE BETWEEN A STEEL FIBER AND CEMENTITIOUS MATRIX IN RELATION TO THE TOUGHNESS OF STEEL FIBER REINFORCED MORTARS Shin-ichi IGARASHI and Mitsunori KAWAMURA
}

\begin{abstract}
The fracture toughness for the interfacial zone between a steel fiber and cementitious matrix was experimentally obtained by applying a compliance method to the single fiber pull-out test. Effects of the addition of silica fume and sand grains, and water : cement ratio on the fracture toughness were discussed relating them to characteristics of the fracture process revealed by the fluorescence microscope. Interfacial fractures under the pullout loading were not a simple shear failure along the real interface. Local failures of the extended regions around a steel fiber were accompanied in the fracture process. The decrease in fracture toughness due to the addition of silica fume can be related to less microcracking in the interfacial zone and less tortuous extension of the interfacial cracks. In order to increase the fracture toughness for the interfacial zone, a small amount of carbon fiber was incorporated into the matrix. The addition of short carbon fibers was effective to improve the fracture toughness and the frictional stress in the interfacial zone. Steel fiber reinforced mortar with the matrix containing silica fume and short carbon fibers exhibited greater M. O. R. and toughness.
\end{abstract}

